\title{
Hospitalization for community-acquired pneumonia in Alberta patients with human immunodeficiency virus infection: A case control study
}

\author{
David $\mathrm{H}$ Johnson $\mathrm{MD}^{1}$, Keumhee C Carriere $\mathrm{PhD}^{2}$, Stan Houston $\mathrm{MD}^{3}$, Yan Jin $\mathrm{MA}^{4}$, Gerry Predy $\mathrm{MD}^{5}$, \\ John Gill MD', Stephen Shafran $\mathrm{MD}^{3}$, Thomas J Marrie $\mathrm{MD}^{3}$
}

\begin{abstract}
DH Johnson, KC Carriere, S Houston, et al. Hospitalization for community-acquired pneumonia in Alberta patients with human immunodeficiency virus infection: A case control study. Can Respir J 2003;10(5):265-270.
\end{abstract}

BACKGROUND: To determine whether outcomes of pneumonia among human immunodeficiency virus (HIV)-positive persons differed from those among HIV-negative persons.

METHODS: Alberta hospital patient abstracts for HIV-positive persons requiring hospitalization for pneumonia from April 1, 1994, until March 31, 1999, were matched by age and sex with four HIVnegative counterparts.

RESULTS: Hospitalizations for community-acquired pneumonia decreased for those with HIV (acquired immunodeficiency syndrome [AIDS]) and increased for those with HIV (non-AIDS) during the study period. HIV (AIDS) patients admitted for community-acquired pneumonia $(\mathrm{n}=130)$ manifested three times higher odds for a longer length of hospital stay and had three and 10 times higher odds for excess in-hospital and one-year mortality, respectively, than their matched controls. Similarly, HIV (non-AIDS) patients admitted for community-acquired pneumonia $(n=46)$ manifested two times higher odds for a longer length of hospital stay and had four times higher odds for excess one-year mortality than their matched controls. The in-hospital and one-year mortality rates for the HIV (AIDS) patients were $21.2 \%$ and $64.3 \%$, respectively, during the first three years, and decreased to $8.7 \%$ and $40.7 \%$, respectively, in the last two years of the study.

CONCLUSIONS: The outcomes for community-acquired pneumonia were worse for those with HIV (non-AIDS) and HIV (AIDS) compared with non-HIV hospitalized patients matched for age and sex, and controlling for severity of illness and comorbidity. In-hospital and one-year mortality rates for patients with HIV (AIDS) showed a marked decline over the study period.

Key Words: Community-acquired pneumonia; Health service utilization; Human immunodeficiency virus infection

\section{Hospitalisation en raison de pneumonie extra-hospitalière chez des patients albertains atteints d'une infection par le virus de l'immunodéficience humaine : étude cas-témoins}

CONTEXTE : Déterminer s'il existe des différences dans l'issue de la pneumonie entre les personnes séropositives pour le virus de l'immunodéficience humaine $(\mathrm{VIH})$ et les personnes séronégatives.

MÉTHODES : Au moyen des résumés d'hôpitaux, chacun des patients albertains séropositifs hospitalisés en raison d'une pneumonie entre le $1^{\text {er }}$ avril 1994 et le 31 mars 1999 ont été appariés selon l'âge et le sexe à quatre patients séronégatifs.

RÉSULTATS : Les hospitalisations attribuables à une pneumonie extrahospitalière ont diminué chez les sujets atteints du VIH (syndrome d'immunodéficience humaine [sida]) et ont augmenté chez les sujets atteints du VIH (mais non du sida) au cours de la période étudiée. Les patients atteints du VIH (sida) admis en raison d'une pneumonie extra-hospitalière $(\mathrm{n}=130)$ présentaient un risque trois fois plus élevé que les témoins appariés de séjourner plus longtemps à l'hôpital, ainsi que des risques trois fois et dix fois plus élevés de surmortalité durant l'hospitalisation et après un an respectivement. De même, les patients atteints du VIH (mais non du sida) admis en raison d'une pneumonie extra-hospitalière $(n=46)$ présentaient un risque deux fois plus élevé que les témoins appariés de séjourner plus longtemps à l'hôpital ainsi qu'un risque quatre fois plus élevé de surmortalité à un an. Les taux de mortalité à l'hôpital et à un an pour les patients atteints du VIH (sida), qui étaient de $21,2 \%$ et de $64,3 \%$, respectivement, au cours des trois premières années de l'étude, ont diminué pour passer à $8,7 \%$ et à $40,7 \%$, respectivement, au cours des deux dernières années.

CONCLUSIONS : Après la prise en compte de la gravité de la maladie et de la comorbidité, l'issue de la pneumonie extra-hospitalière a été moins favorable pour les patients atteints du VIH, qu'ils soient atteints ou non du sida, que pour des patients séronégatifs appariés selon l'âge et le sexe. Chez les patients atteints du VIH (sida), il y a eu une baisse marquée des taux de mortalité à l'hôpital et à un an au cours de la période étudiée.
$\mathrm{T}$ he rate of pneumonia has been shown to be very high among human immunodeficiency virus (HIV)-infected persons 5.5 episodes $/ 100$ person-years compared with a rate of $0.9 / 100$ person-years among HIV-negative persons (1). There is an incremental increase in the rate of pneumonia as the CD4 count declines. Thus, for CD4 counts greater than 500, between 200 and 500, and less than 200, the rates of pneumonia are 2.3, 6.8 and 10.8/100 person-years, respectively (1). In April 1997, highly active antiretroviral therapy (HAART) was added to the Alberta provincial formulary as a multiple drug regimen effective

${ }^{1}$ Department of Critical Care Medicine, ${ }^{2}$ Department of Mathematical and Statistical Sciences, ${ }^{3}$ Department of Medicine, University of Alberta, Edmonton, Alberta; ${ }^{4}$ Information Analysis, Alberta Health and Wellness, Edmonton, Alberta; ${ }^{5}$ Capital Health Authority, Edmonton, Alberta; ${ }^{6}$ Department of Medicine, University of Calgary, Calgary, Alberta

Correspondence: Dr David Johnson, 368 O'Connor Close, Edmonton, Alberta T6R 1L4. Telephone 780-435-0530, fax 780-435-9083, e-mail cujecjohnson@shaw.ca 
against HIV. Studies comparing the pulmonary manifestations of HIV infection pre- and postintroduction of HAART have found a reduction in the rate of Pneumocystis carinii pneumonia (PCP) $(2,3)$ and an increase in (2) or a stable rate of bacterial pneumonia (3). In the present study, an administrative data set was used to study HIV-positive pneumonia patients requiring hospitalization in Alberta from April 1, 1994 until March 31, 1999. Our objectives were to determine whether outcomes of pneumonia in HIV-positive persons differed from those who were HIV-negative. To accomplish this objective, each HIV-positive patient with pneumonia was matched (by age and sex) with four HIVnegative patients with pneumonia.

\section{METHODS}

Use of the administrative health service database and analysis were completed within the protected environment of Alberta Health and Wellness (Edmonton, Alberta), which is governed by provincial legislative guidelines on the confidentiality of health information.

\section{Inclusion criteria}

The Canadian Institute for Health Information's Inpatient Discharge Abstract Database for the province of Alberta from April 1, 1994 to March 31, 1999 was used for the study. Community-acquired pneumonia was defined as the most responsible diagnosis or any of the other 15 diagnosis codes defined to be type 1 (preadmit comorbidity), with International Classification of Diseases, Ninth Revision, Clinical Modification (ICD-9CM) codes 480 to 487 (pneumonia) or 507 (aspiration pneumonia), excluding code 484 (pneumonia of infectious diseases classified elsewhere) $(4,5)$. Symptomatic HIV infection was defined as ICD-9CM code 042 in any of the 16 diagnosis codes. Asymptomatic HIV infection was defined as ICD-9CM code V08 in any of the 16 diagnosis codes. A one patient to four patient matched case-control design was used. The data were matched according to age, sex and year of pneumonia diagnosis. First, HIV (acquired immunodeficiency syndrome [AIDS]) or HIV (non-AIDS) patients were idenified in the entire cohort. The data were divided to identify HIV (non-AIDS) patients. Then, for each HIV (AIDS) and HIV (non-AIDS) case, control patients were randomly sampled who matched the case patient by age, sex and year of pneumonia diagnosis.

\section{Exclusion criteria}

- not an Alberta resident or not treated in an Alberta acute care facility

- adjacent diagnosis related group defining hospitalization for a surgical procedure

- any previous hospitalization within 10 days of incident pneumonia case

\section{Definition of severe illness}

- transfer among acute care facilities as defined by readmission to another hospital for the diagnosis of pneumonia within $48 \mathrm{~h}$ of previous discharge
- special or intensive care unit admission (defined by each hospital)

- diagnosis codes for respiratory failure or arrest (ICD9-CM 518.81, 799.1)

- diagnosis codes for hypotension or shock (ICD9-CM 458, 758.5)

- procedure code for ventilation longer than $96 \mathrm{~h}$ (ICD9-CM 96.72)

- procedure codes for dialysis (ICD9-CM 39.95, 54.98)

\section{Comorbidity}

Charlson's comorbidity index was calculated using established definitions $(6,7)$. Length of stay was calculated as the number of days between admission and discharge. All active hospital acute care beds in each year per resident region were surveyed and maintained in the provincial databases. Export was defined as primary admission to a hospital not within the patient's region of residence.

\section{Defining hospital type by patient volume}

Hospitals admitting patients with community-acquired pneumonia were categorized into five groups based on the average number of hospital discharges per year over the five-year study period, geographic location and medical school proximity.

- Rural hospitals were categorized by number of pneumonia cases (with $n=50$ and $n=108$ representing the 50th and 75 th percentiles, respectively) into: less than 50 cases/year (77 hospitals) and 50 to 108 cases/year (27 hospitals).

- Regional hospitals $(\mathrm{n}=5)$ included each of the five nonmetropolitan, regional health care cities (67 to 251 cases/year), and one high volume rural hospital (221 cases/year) was also added to this group.

- Metropolitan hospitals $(\mathrm{n}=7)$ hospitals were located in the metropolitan health regions of Calgary and Capital (92 to 813 cases/year).

- Medical school metropolitan hospitals ( $\mathrm{n}=2)$ were located adjacent to medical schools - one hospital was located in each of two metropolitan centres (493 and 610 cases/year).

\section{Hospital costs}

Inpatient cost per resource group number was calculated using the provincially approved methodology set forth by the provincial costing project in accordance with the Guidelines for Management Information Systems in Canadian Health Service Organizations $(8,9)$. Total costs combined allocation and assignment of all direct and indirect costs associated with an inpatient encounter from the time of admission to the time of discharge. All costs were estimated in 1998/1999 and were 
TABLE 1

Group demographics for patients with hospitalized community-acquired pneumonia in Alberta from 1994/1995 to $1998 / 1999$

\begin{tabular}{|c|c|c|c|}
\hline & $\begin{array}{l}\text { Hospital discharges in } \\
\text { those with HIV (AIDS) } \\
\qquad(n=130)\end{array}$ & $\begin{array}{l}\text { Hospital discharges in } \\
\text { those with HIV (non-AIDS) } \\
\qquad(n=46)\end{array}$ & $\begin{array}{c}\text { Hospital discharges in } \\
\text { non-HIV patients* } \\
(n=704)\end{array}$ \\
\hline Female (n) (\%) & $29(22.3 \%)$ & $19(41.3 \%)$ & $192(27.3 \%)$ \\
\hline Mean age (years) & 38.5 & 36.3 & 37.7 \\
\hline Urban region of residence $(n)(\%)$ & $107(82.3 \%)$ & $36(78.3 \%)$ & $274(38.9 \%)$ \\
\hline Urban region of service $(n)(\%)$ & $114(87.7 \%)$ & $39(84.8 \%)$ & $286(40.3 \%)$ \\
\hline Mean number of comorbidities & 1.36 & 0.46 & 0.45 \\
\hline Mean use of special medical care per patient ${ }^{\dagger}$ & 0.21 & 0.22 & 0.19 \\
\hline
\end{tabular}

${ }^{*}$ Comparative non-human immunodeficiency virus (non-HIV) group is matched for age and sex; tRefers to any of the following: transfer from another acute care facility, special or intensive care unit admission, respiratory failure or arrest, ventilation longer than 96 h, hypotension or shock and/or in-hospital dialysis. AlDS Acquired immunodeficiency syndrome

assumed to be similar for all study years. The quality of the data reporting of costs in Alberta has been highly ranked by the Canadian Institute for Health Information (10). As such, the methodological issues that arise around the collection of cost data - in the United States (11), in part because of the use of charges rather than costs, and for some centres in Canada, because the cost of admissions is based on 'case-mix grouping' - do not arise with the majority of the cost data considered in this analysis.

\section{Mortality}

Vital statistics declaration of death certificates were merged with the Alberta Health Care Premium Registry database to determine deregistration from the plan. Reliability of linkage was high (99.5\%), as verified by comparing in-hospital deaths recorded by hospital chart extraction with Alberta Health Care Premium Registry deaths derived from vital statistics.

\section{Outcomes used in analyses}

- number of patients with HIV infection in Alberta

- length of hospital stay longer than the median (ie, longer than six days)

- hospital cost greater than the median (ie, greater than $\$ 637.72$ )

- in-hospital death

- one-year mortality after hospital discharge (excluding in-hospital deaths)

- 30-day, all-cause hospital readmission

Registries of the number of HIV-positive patients are kept at HIV clinics in Calgary and Edmonton, Alberta. Patients who were HIV-positive and patients who met the revised surveillance case definition for AIDS in Canada (12) were recorded on April 1 of each year. These registries account for most, but not all, of the HIV-positive patients in Alberta. These numbers were used as the denominator to calculate pneumonia attack rates.

\section{Statistics}

Crude hospital discharge rates and CIs for patients with community-acquired pneumonia were calculated from April 1, 1994 to March 31, 1999. The denominator for these calculations was all patients with positive HIV (non-AIDS) or HIV (AIDS) status who were registered at either the Calgary or Edmonton HIV clinics. Because of the low number of hospital discharges and the introduction of HAART therapy in April 1997, data were aggregated from April 1, 1994 to March 31, 1997 and April 1, 1997 to March 31, 1999.

To analyze the case-control data, LogXact Version 2.0 (Cytel Software Corporation, USA), a conditional logistical analysis tool, was used. Covariates were diagnosis of AIDS, diagnosis of HIV, year of pneumonia diagnosis, age, sex, exported case (ie, service region not equal to recipient region), urban or nonurban resident region, hospital transfer, special or intensive care unit admission, diagnosis code for respiratory failure or arrest, diagnosis code for hypotension or shock, procedure code for ventilation longer than $96 \mathrm{~h}$, procedure code for dialysis and number of comorbid diagnosis (zero, one, two and more than two). The unit of analysis was hospital discharge, with some patients being hospitalized on multiple occasions per year. In previous, related studies, it was verified that ignoring correlation in multiple hospitalizations per person did not result in any loss of information. Therefore, we report the results of a standard, conditional logistical model $(13,14)$.

\section{RESULTS}

Table 1 contains the demographic data for the three study populations: those with HIV (AIDS) infection $(n=130)$, those with HIV (non-AIDS) infection $(n=46)$ and the control group without HIV infection $(n=704)$. Figure 1 shows the yearly discharge rate for community-acquired pneumonia in patients with HIV (non-AIDS) and HIV (AIDS). We estimated the prevalence of those with HIV (AIDS) and HIV (nonAIDS) from metropolitan clinic registries. In those with HIV (AIDS), the rate of hospitalization for community-acquired pneumonia decreased from $15.3 \%$ (95\% CI $12.8 \%$ to $18.2 \%$ ) in the first three years of the study to $9.9 \%$ (95\% CI $7.0 \%$ to $12.4 \%$ ) in the last two years of the study. In those with HIV (non-AIDS), the rate of hospitalization for communityacquired pneumonia increased from $0.6 \%$ (95\% CI $0.3 \%$ to $0.9 \%)$ in the first three years of the study to $1.9 \%(95 \% \mathrm{CI}$ $1.3 \%$ to $2.5 \%$ ) in the last two years of the study. Women com- 


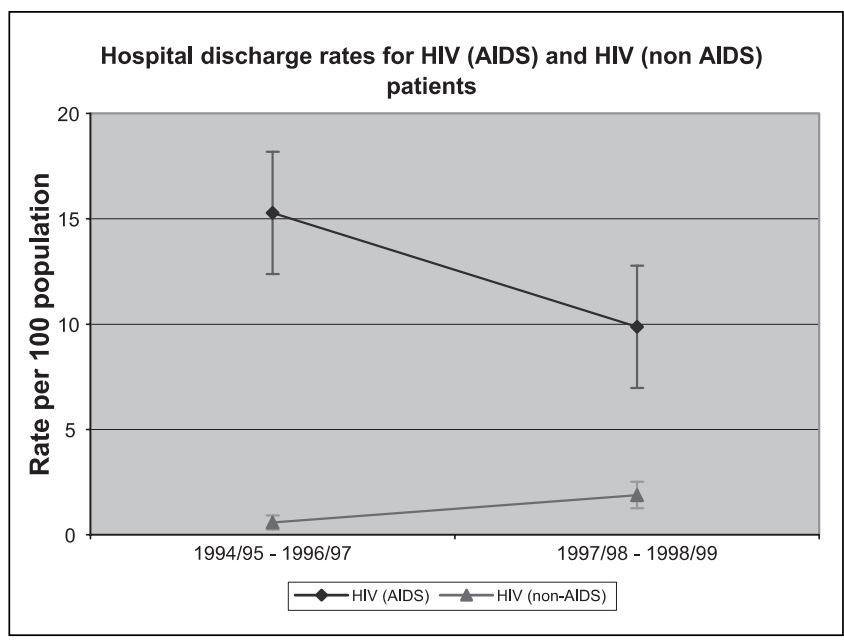

Figure 1) Discharge rate for human immunodeficiency virus (HIV) (acquired immunodeficiency syndrome [AIDS]) and HIV (non-AIDS) patients in the first three years and last two years of the study. Because of low numbers and the introduction of highly active antiretroviral therapy in April 1997, data were aggregated. Denominators were estimated from an HIV/AIDS registry census in the two metropolitan cities

prised $41 \%$ of the HIV (non-AIDS) patients with pneumonia and $22 \%$ of the HIV (AIDS) patients with pneumonia. The majority of the HIV-positive patients with pneumonia had AIDS. Those with HIV (AIDS) and HIV (non-AIDS) predominately resided and were hospitalized in an urban region. The mean number of comorbidities and multiple discharges for pneumonia (Table 2) was higher in those with HIV (AIDS).

The all-cause, 30-day readmission rates were higher for HIV (AIDS) patients than for HIV (non-AIDS) or non-HIV patients. The in-hospital and one-year mortality rates were higher for HIV (AIDS) patients. The yearly mortality rate for HIV (AIDS) patients with community-acquired pneumonia requiring hospitalization is shown in Figure 2. The in-hospital mortality rate for HIV (AIDS) patients was $21.2 \%$ from April 1, 1994 to March 31, 1997 and decreased to 8.7\% in the last two years of the study (April 1, 1997 to March 31, 1999). The one-year mortality rate for HIV (AIDS) patients was $64.3 \%$ and decreased to $40.7 \%$ during these same periods, respectively.
By multivariate analysis (Table 3), the following were found to be associated with a prolonged length of stay: HIV (AIDS) and HIV (non-AIDS), transfer to another acute hospital, special care unit admission, admission to a metropolitan hospital and comorbidity. Lower costs were associated with transfer to an acute hospital and more comorbidity. Hypotension or shock significantly increased the odds of in-hospital and one-year mortality. In addition, HIV (non-AIDS) increased the odds of one-year mortality. Hospital readmission was not associated with any of the covariates considered.

\section{DISCUSSION}

HIV (AIDS) patients admitted for community-acquired pneumonia manifested three times higher odds for a longer length of hospital stay, three times higher odds for excess in-hospital mortality and 10 times higher odds for excess one-year mortality than their non-HIV matched controls. Similarly, HIV (non-AIDS) patients admitted for community-acquired pneumonia manifested twice higher odds for a longer length of hospital stay and four times higher odds for excess one-year mortality than their matched controls. Hospital readmissions were more frequent for those with HIV (AIDS) than non-HIV matched controls and those with HIV (non-AIDS), but this did not reach statistical significance. The outcomes for community-acquired pneumonia were worse for those with HIV (non-AIDS) and HIV (AIDS) after matching non-HIV patients for age and sex, and controlling for severity of illness and comorbidity.

Hospitalizations for community-acquired pneumonia decreased for those with HIV (AIDS) and increased for those with HIV (non-AIDS) during the study period. We also noted temporal changes in the frequency of hospitalizations for community-acquired pneumonia in those with HIV (non-AIDS) and HIV (AIDS) compared with their non-HIV matched controls. Touchie and Marrie (15) matched 32 hospitalized HIV (non-AIDS) and HIV (AIDS) patients with pneumonia to 33 non-HIV hospitalized pneumonia patients by age and sex. This study was carried out in Halifax, Nova Scotia from September 1991 to October 1993. Fifty per cent of the HIV (non-AIDS) and HIV (AIDS) patients had PCP versus none of the nonHIV patients. The in-hospital mortality rates in that study were $25 \%$ and $0 \%$, and the one-year mortality rates were $70 \%$ and $6 \%$ for the HIV (AIDS) and HIV (non-AIDS) patients,

TABLE 2

Outcomes for hospitalized community-acquired pneumonia groups in Alberta from 1994/1995 to $1998 / 1999$

\begin{tabular}{|c|c|c|c|}
\hline $\begin{array}{l}\text { Hos } \\
\text { thos }\end{array}$ & $\begin{array}{l}\text { oital discharges in } \\
\text { se with HIV (AIDS) } \\
(n=130)\end{array}$ & $\begin{array}{l}\text { Hospital discharges in } \\
\text { those with HIV (non-AIDS) } \\
\qquad(n=46)\end{array}$ & $\begin{array}{l}\text { Hospital discharges in } \\
\text { non-HIV patients* } \\
(n=704)\end{array}$ \\
\hline Unique persons $(\mathrm{n})$ & 100 & 42 & 704 \\
\hline Hospital discharges per unique person (n) & 1.30 & 1.10 & 1.01 \\
\hline Mean length of stay (days) (median) & $9.9(7)$ & $7.3(5)$ & $5.4(4)$ \\
\hline Number of all-cause, 30-day readmissions (\%) & $25(23.1)$ & $5(11.1 \%)$ & $95(14.0 \%)$ \\
\hline Number of in-hospital mortalities (\%) & $22(16.9)$ & $1(2.2 \%)$ & $26(3.7 \%)$ \\
\hline Number of Alberta residents who died within one year postdischarge (\%) & $76(59.4)$ & $8(18.6 \%)$ & $57(8.4 \%)$ \\
\hline Average daily hospital cost & $\$ 669$ & $\$ 601$ & $\$ 749$ \\
\hline Average hospital cost per hospital discharge & $\$ 6,629$ & $\$ 4,417$ & $\$ 4,058$ \\
\hline
\end{tabular}

${ }^{*}$ Comparative nonhuman immunodeficiency virus (non-HIV) group is matched for age and sex. AIDS Acquired immunodeficiency syndrome 
respectively. In the present study, the in-hospital and one-year mortality rates for those with HIV (AIDS) were 16.9\% and $59 \%$, respectively. The in-hospital mortality and one-year mortality rates were $2.2 \%$ and $19 \%$, respectively, for those with HIV (non-AIDS). Park et al (16) studied 112 HIV-positive and $410 \mathrm{HIV}$-negative patients admitted to the Harborview Hospital (Seattle, Washington) with community-acquired pneumonia from June 1994 to May 1996. Thirty-one per cent of the HIV-positive patients had PCP compared with none of the HIV-negative patients. Fourteen per cent of the HIV-positive patients in Park et al's study were female compared with $27 \%$ in the present study. The in-hospital mortality rate was $8.9 \%$ for the HIV-positive patients in the present study compared with 3.7\% for the HIV-negative patients in Park et al's study (16). Another study found that there was no significant difference in the in-hospital mortality rates between HIV-positive patients (10.6\%) and HIV-negative patients (7.8\%) (17).

We used an administrative database to study the temporal trends in pneumonia in HIV-infected persons in Alberta. Identification of those with HIV (non-AIDS) and HIV (AIDS) was dependent on hospital abstraction. We did not verify the quality of hospital extraction, which would have required sampling over 40,000 charts in more than one hundred hospitals. However, it was reasonable to assume that HIV status was well documented in hospital records. Populationbased administrative database research is highly generalizable, although limited in clinical details. We were unable to identify all HIV (non-AIDS) and HIV (AIDS) individuals at risk for community-acquired pneumonia hospitalization. The estimated number of HIV individuals at risk for community-acquired pneumonia hospital published by Health Canada is lower than the number of patients treated at the two major HIV/AIDS clinics in Edmonton and Calgary. The HIV (non-AIDS) group may have been hetergeneous with some HIV (non-AIDS) patients misclassified as HIV (AIDS) patients, especially in the early study years, confounding the differentiation between these two groups. We attempted to adjust for case severity

\section{Yearly mortality rate for HIV (AIDS) patients with community acquired pneumonia requiring hospitalization}

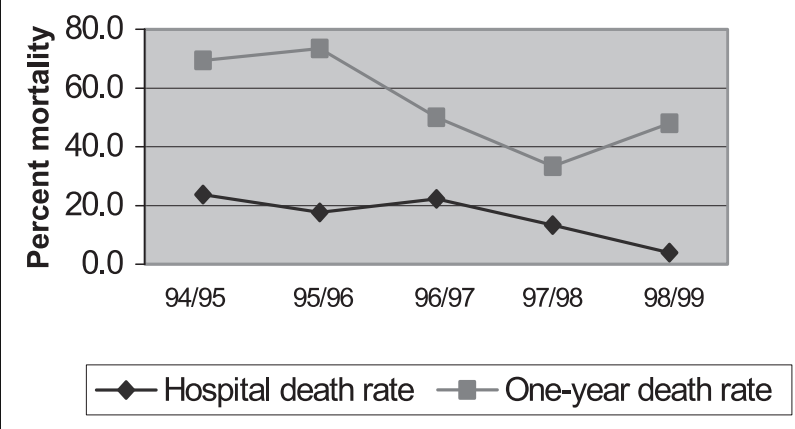

Figure 2) Mortality rate for human immunodeficiency virus (HIV) (acquired immunodeficiency syndrome [AIDS]) patients admitted with community-acquired pneumonia

(hypotension or shock, respiratory arrest or failure, ventilation, special care unit admission, export to another region, transfer to another hospital) and case mix (comorbidity, transfer from nursing home, age, sex), but may not have captured all variation (18). These variables likely are less reliable than a clinically derived pneumonia index (19).

Notwithstanding these limitations, however, this particular study design also has strengths. We were readily able to determine the readmission rate and one-year mortality rate using population-based data. As well, we were able to estimate cost the cost of pneumonia treatment for patients with HIV (AIDS) was $\$ 1,571$ higher per episode than for non-HIV patients. The cost for HIV (non-AIDS) patients was similar to that for non-HIV patients. After adjusting for severity of ill-

TABLE 3

Outcome odds ratios (95\% Cls) for hospitalized commuity-acquired pneumonia groups in Alberta from $1994 / 1995$ to $1998 / 1999$

\begin{tabular}{|c|c|c|c|c|c|}
\hline & $\begin{array}{l}\text { Length of stay } \\
\text { longer than median } \\
\text { six days }\end{array}$ & $\begin{array}{c}\text { Hospital cost } \\
\text { greater than median } \\
\$ 637.72 / \text { day }\end{array}$ & $\begin{array}{c}\text { 30-day } \\
\text { readmissions }\end{array}$ & $\begin{array}{l}\text { In-hospital } \\
\text { mortality }\end{array}$ & $\begin{array}{l}\text { One-year } \\
\text { mortality }\end{array}$ \\
\hline HIV (AIDS) & $3.0(1.68$ to 5.36$)$ & $0.99^{*}(0.59$ to 1.69$)$ & NS & $3.39(1.32$ to 8.70$)$ & 10.09 (4.78 to 21.33$)$ \\
\hline HIV (non-AIDS) & $2.12(1.02$ to 4.40$)$ & $0.79 *(0.41$ to 1.5$)$ & NS & $0.83^{*}(0.07$ to 9.76$)$ & 4.33 (1.36 to 13.82$)$ \\
\hline Transfer to acute hospital & 4.43 (1.40 to 14.07$)$ & 0.30 (0.11 to 0.79$)$ & NS & NS & NS \\
\hline Special or intensive care admission & 2.98 (1.55 to 5.73$)$ & NS & NS & NS & NS \\
\hline Rural hospital (50 to 108 cases/year) & $0.36(0.016$ to 0.81$)$ & NS & NS & NS & NS \\
\hline Regional hospital & $1.57(0.77$ to 3.20$)$ & NS & NS & NS & NS \\
\hline Urban hospital (metropolitan) & 2.27 (1.22 to 4.23$)$ & NS & NS & NS & NS \\
\hline $\begin{array}{l}\text { Urban hospital (metropolitan hospital in } \\
\text { close proximity to medical school) }\end{array}$ & $1.96(0.98$ to 3.92$)$ & NS & NS & NS & NS \\
\hline One comorbidity & $1.44(0.88$ to 2.35$)$ & 1.89 (1.26 to 2.83$)$ & NS & 2.24 (0.68 to 7.33$)$ & $4.54(1.85$ to 11.15$)$ \\
\hline Two comorbidities & 2.24 (1.11 to 4.53$)$ & 1.53 (0.86 to 2.74$)$ & NS & $7.81(2.21$ to 27.51$)$ & $19.53(6.80$ to 56.07$)$ \\
\hline More than two comorbidities & $3.86(1.04$ to 14.33$)$ & 1.59 (0.56 to 4.53$)$ & NS & 39.15 (3.42 to 448.78$)$ & 25.60 (5.0 to 131.01$)$ \\
\hline Hypotension or shock & NS & NS & NS & 8.70 (1.88 to 40.28$)$ & 11.93 (2.65 to 53.61$)$ \\
\hline
\end{tabular}

*Human immunodeficiency virus (HIV) (non-acquired immunodeficiency syndrome [non-AIDS]) and HIV (AIDS) were forced in the final model even though they were not significant (NS) 
ness and comorbidity, the risk of hospital costs greater than the median were similar in those with HIV (non-AIDS) and HIV (AIDS) compared with their non-HIV matched controls.

\section{CONCLUSIONS}

Hospitalizations for community-acquired pneumonia decreased for those with HIV (AIDS) and increased for those with HIV (non-AIDS) during the study period. The outcomes measured (length of hospital stay, mortality) were worse for those with HIV (non-AIDS) and HIV (AIDS) than for non-

\section{REFERENCES}

1 Hirschtick RE, Glassroth J, Jordan MC, et al. Bacterial pneumonia in persons infected with the human immunodeficiency virus. N Engl J Med 1995;333:845-51.

2 Wolff AJ, O'Donnell AE. Pulmonary manifestations of human immunodeficiency virus infection in the era of highly active antiretroviral therapy. Chest 2001;120:1888-93.

3. Ives NJ, Gazzard BG, Easterbrook PJ. The changing pattern of AIDS-defining illnesses with the introduction of highly active antiretroviral therapy (HAART) in a London clinic. J Infect 2001;42:134-9.

4. Marrie TJ, Durant H, Sealy E. Pneumonia - The quality of medical records. Med Care 1987;25:20-4.

5. Draper D, Kahn KL, Reinisch EJ, et al. Studying the effects of the DRG based prospective payment system on quality of care. JAMA 1990;264:1956-61.

6. Deyo RA, Cherkin DC, Ciol MA. Adapting a clinical comorbidity index for use with ICD-9-CM administrative databases. J Clin Epidemiol 1992;45:613-9.

7. Romano PS, Roos LL, Jollis JG. Adapting a clinical comorbidity index for use with ICD-9-CM administrative data: differing perspectives. J Clin Epidemiol 1993;46:1075-9.

8. Guidelines for Management Information Systems in Canadian Health Service Organizations. Ottawa: Canadian Institute for Health Information, 1999.

9. Regional Health Authority Global Funding Manual, 2000/01. Funding Health Resourcing Branch. Edmonton: Alberta Health and Wellness, 2000.
HIV hospitalized patients matched for age and sex, and controlling for severity of illness and comorbidity. In-hospital and one-year mortality rates for patients with HIV (AIDS) showed a marked decline over the study period.

ACKNOWLEDGEMENTS: This work was partially supported by the Alberta Centre for Health Service Utilization Research. The opinions and conclusions expressed in this paper are those of the authors, and no endorsement by the Alberta Ministry of Health and Wellness is implied.

10. McKillop I, Pink GH, Johnson LM. The Financial Management of Acute Care in Canada: A Review of Funding, Performance Monitoring and Reporting Practices. Ottawa: Canadian Institute for Health Information, 2001:83.

11. Magnus SA, Smith DG. Better Medicare Cost Report data are needed to help hospitals benchmark costs and performance. Health Care Manage Rev 2000;25:65-76.

12. Revision of the surveillance case definition for AIDS in Canada. CMAJ 1994;150:531-2.

13. Seber GAF. Linear Regression Analysis. New York: Wiley, 1977.

14. Hosmer DW, Lemeshow S. Applied Logistic Regression. New York: John Wiley and Sons, 1989.

15. Touchie C, Marrie TJ. Comparison of community-acquired pneumonia requiring admission to hospital in HIV and non-HIV patients. Can J Infect Dis 1996;7:253-8.

16. Park DR, Sherbin VL, Goodman MS, et al. Harborview CAP Study Group. The etiology of community-acquired pneumonia at an urban public hospital: Influence of human immunodeficiency virus infection and initial severity of illness. J Infect Dis 2001;184:268-77.

17. Mundy LM, Auwaerter PG, Oldach D, et al. Community-acquired pneumonia: Impact of immune status. Am J Respir Crit Care Med 1995;152:1309-15.

18. Ewig S, Ruiz M, Mensa J, et al. Severe community-acquired pneumonia. Assessment of severity criteria. Am J Respir Crit Care Med 1998;158:1102-8.

19. Marrie TJ, Lau CY, Wheeler SL, Wong CJ, Vandervoort MK, Feagan BG. A controlled trial of a critical pathway for treatment of community-acquired pneumonia. JAMA 2000;283:749-55. 


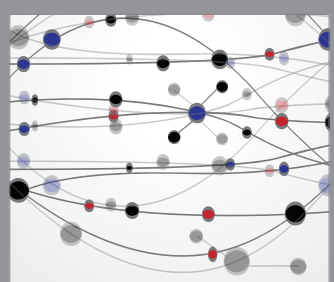

The Scientific World Journal
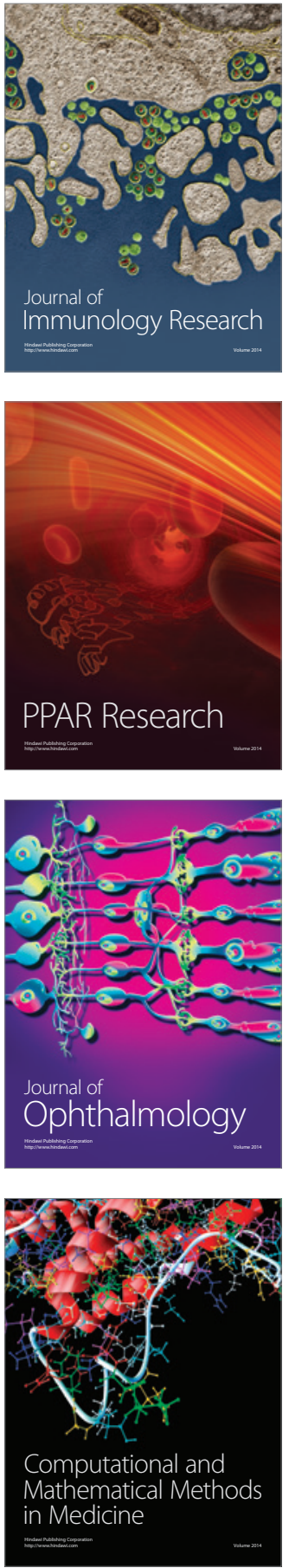

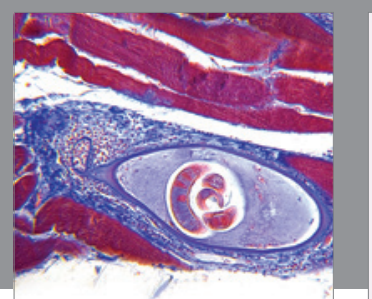

Gastroenterology Research and Practice

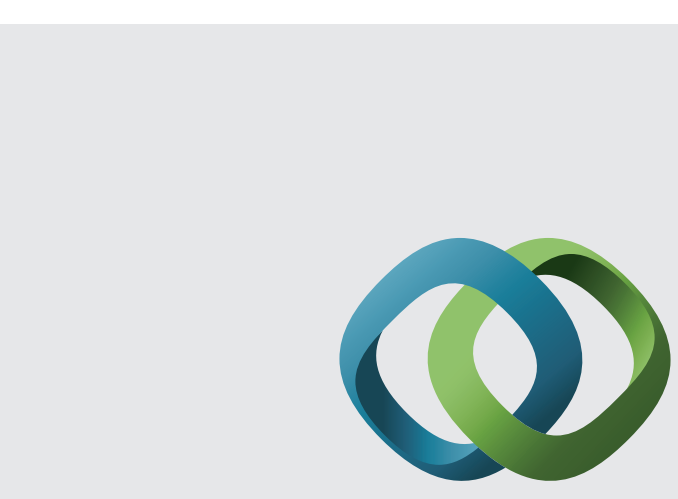

\section{Hindawi}

Submit your manuscripts at

http://www.hindawi.com
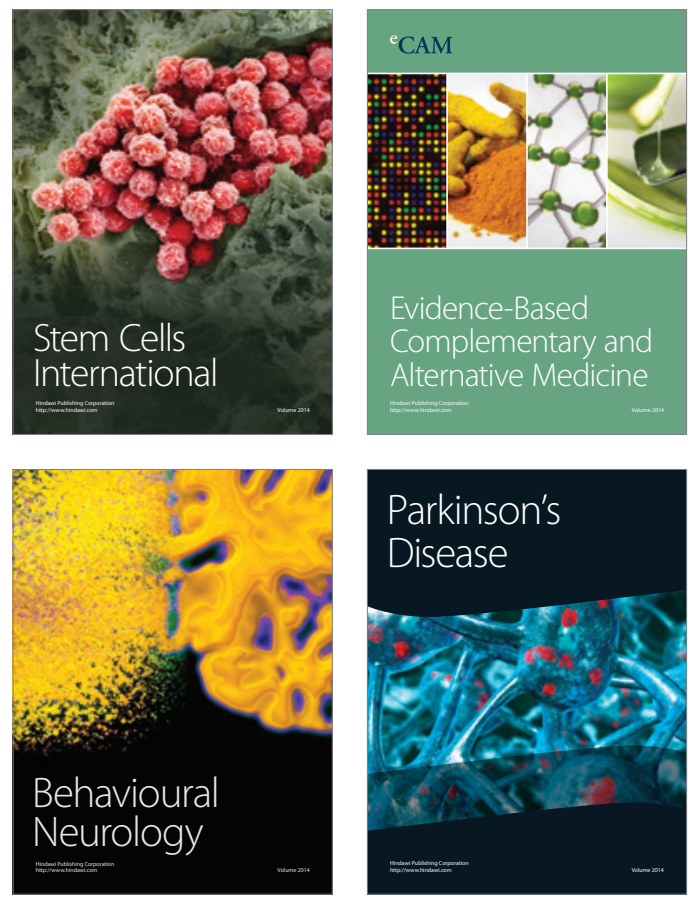
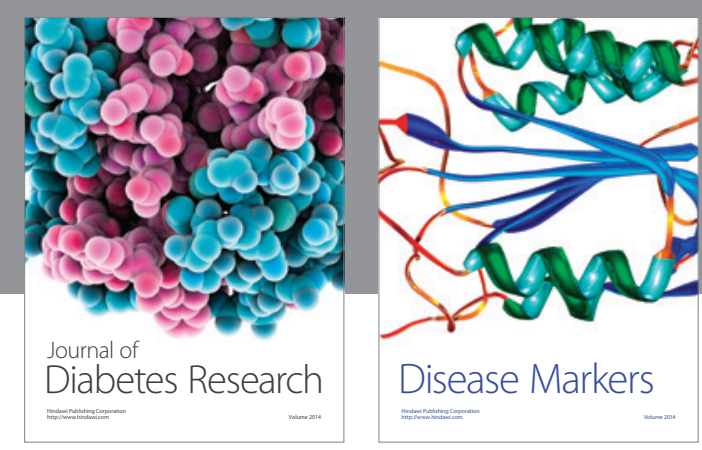

Disease Markers
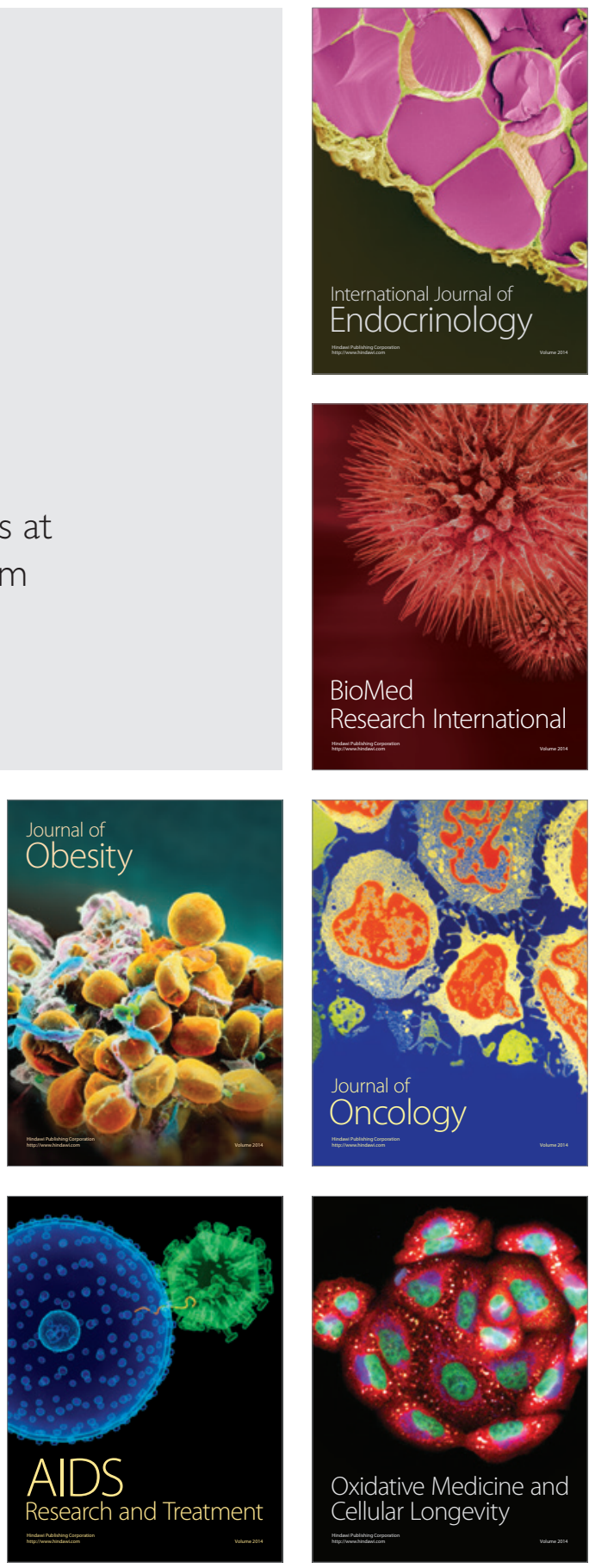